\title{
Galina Lesnaya
}

MGIMO University, Russia, Moscow

glesnaya@gmail.com

\section{Methodology for a text research in Kiev edition of "The Tale of Igor's Campaign" by V.M. Peretz, 1926}

Linguistic and literary analysis of Old Russian literature's texts implies that a special methodology of studying should be employed. Such a methodology was developed by V. N. Peretz at his "Seminary", while he was teaching at St. Vladimir's University in Kiev and at Petrograd University. In the article the principles of reading the text proposed by the scholar are reviewed basing on "The Tale of Igor's Campaign", published by V.N. Peretz in Ukrainian in Kiev in 1926.

Keywords: methodology of textual analysis, V.N. Peretz, "The Tale of Igor's Campaign"

\section{Марианна Лявинец-Угрин}

DOI: $10.31168 / 91674-576-4.15$

Будапештский университет им. Л. Этвеша, Венгрия mariann.ljavinecz@gmail.com

\section{Азъ-Буки-Веди (Андрей Бачинский Владыка) Кириллические циркуляры епископа А. Бачинского}

В этой работе мы попытались обобщить сведения о памятниках письменности епископа Андрея Бачинского. Речь пойдет о кириллических циркулярах и об особенностях традиций письменности карпаторусинов.

Ключевые слова: Андрей Бачинский, кириллические ичиркуляры латинского периода, карпаторусины

Одной из волнующих тем современной карпаторусинистики является исследование кириллических 
памятников письменности величайшего представителя Просвещения - епископа Андрея Бачинского (1732-1809). Время его правления приходится на конец XVIII и начало XIX вв. Это был человек действительно исключительных дарований. За 37 лет управления Мукачевской епархией Бачинский развернул активную и широкую деятельность в сфере образования, добился независимости Мукачевской епархии от Егерской, а также ее равноправия среди других католических епархий в Венгрии. Благодаря его стараниям в Ужгороде был воздвигнут Крестовоздвиженский кафедральный храм, куда был перенесен епископский престол в 1780 г., а также была организована епископская библиотека [Мњсяцеслов 1864: 17]. В 1793 г. он учредил мужскую учительскую семинарию и, будучи в хороших отношениях с императрицей Марией Терезией, попросил разрешения обучать карпаторусинских детей хотя бы отчасти на церковнославянском (т. е. по-русински), а не только на латинском и венгерском языках. Непременно надо отметить, что подобно своим современникам, А. Бачинский отождествлял русинский язык с церковнославянским [Удвари 1984: 99].

В то время официальным языком Венгрии был латинский язык. Поэтому несмотря на то, что в период Просвещения поднялся уровень образования иночества, церковнославянский язык фактически полностью вытеснялся латинским. В периодизации истории русинской письменности этот период принято называть латинским. Одной из самых важных заслуг Бачинского является то, что он попытался вернуть использование кириллицы и церковнославянского языка в среде верующих славян-униатов. В связи с этим Бачинский способствовал изданию библии в 5-ти томах «Библія сиръчъ книги священнаго писанія ветхаго и новаго завъта ...» под редакцией Г. Тарковича (1804-1805 гг.) в Будине. Работа над этим изданием началась в 1794 г. В специальной литературе долгое время велась поле- 
мика, где печаталась Библия: в России или в Будине? На основании архивных документов, а в частности латино- и венгероязычных епископских писем и циркуляров, видный венгерский ученый И. Удвари пришел к тому, что мысль о российском издании данной Библии (предполагалось, что это российская Библия, которая получила новую обложку) оказывается несостоятельной, хотя нет сомнений, что она сделана по московскому образцу [Удвари 1986: 72; Удварі 2000: 80-81; Удварі 2002: 22].

Значительную группу рукописей наследия Бачинского составляют кириллические церковные эпистолярные тексты. Крупные реформы в культурно-национальной и церковной жизни он излагал в окружных циркулярах, или, как их тогда называли, кУрєнсъ (курренсъ / куренсъ) - лат. currere «бегать», «ездить» (в русск. яз. куренда - лат. currere «бъгать» окружное послание [Чудинов 1894: 441]), которые в русинском научном кругу известны как уббіжникы. Циркуляры составлялись по принятым каноническим формам, с употреблением клишированных форм на основе стандартного образца. Циркуляры состояли из трех структурных частей, которые имели собственные формулы, роль и предназначение: вступление, тема и заключение. Согласно проведенным исследованиям, Бачинский выпускал два циркуляра в год (весной и осенью) к ежегодным соборам. Многие циркуляры Бачинский подписывал криптонимом Азъ-Буки-Веди (Андрей Бачинский Владыка), этим же как будто устанавливая общеобязательные каноны как в духовном понимании, так и в образовании письменности русинов. По содержанию их можно разделить на две основные группы: 1) на объясняющие и подытоживающие распоряжения и предписания государственной власти, 2) на посвященные образовательным или духовным вопросам [Удварі 2002: 218-221; Падяк 2011: 307]. Как правило, циркуляры составлялись в канцелярии епископа и рас- 
сылались по епархии. Требовалось изготовить столько копий, во сколько приходов и церковных округов адресовался циркуляр. Большей частью они были занесены в протокольные книги.

Согласно исследованиям А. Шлепецкого, И. Удвари, И. Задорожного и В. Падяка, до сих пор было раскрыто около 80 циркуляров Бачинского, а также их копий. Благодаря обнаруженным копиям был проведен ряд сравнительных грамматических анализов этих текстов. Исследование показало, что в текстах копий налицо индивидуальная характеристика и грамотность переписчиков [Падяк 2011: 312]. Язык посланий и документов Бачинского воспринимался карпаторусинской интеллигенцией того времени как литературная норма, как образец для подражания и соблюдения правил письма. И. Удвари считал, что «корни «язычия», литературного языка Подкарпатья в XIX в., прослеживаются в языковой норме канцелярии Бачинского». Ввиду этого «язычие» никак не может быть случайным лингвистическим образованием. «Это скорее плод длительного и естественного развития, опирающегося главным образом на язык, который употреблялся в циркулярах Бачинского» [Удварі 2002: 220-221]. Было бы неправильным считать, что тексты написаны язычием, а в данном случае циркуляры Бачинского написаны неграмотно или же на неправильном языке. На наш взгляд, здесь идет речь о гибридных текстах, которые в силу сложившихся как исторических, так и географических факторов образовали свою особенную традицию письменности. Характерным элементом этой традиции является переплетение церковнославянского, славяно-русского языка с вкраплением иноязычной лексики.

Циркуляры Бачинского главным образом являлись переводами с латинского (т.е. административного языка) или венгерского (т.е. разговорного субстрата) языков, реже, авторскими текстами. В ходе наших иссле- 
дований стало явным, что заимствованная лексика в основном присуща тем циркулярам, которые посвящены образовательным или духовным вопросам, а также встречается в переводческих текстах. Например, в документе из «Совђта Царскаго объявленія», который изначально был написан на латинском языке, мы встречаем следующую фразу: «Gнкою жестоко запрҺщаетсга ПароХШМъ Аа ЗМакН КаноннческН: ПОАСЫ червеной мастн Штрымфић ройты Панткнкн: Аа не носгатъ» [Падяк 2011: 323]. В этом предложении объяснения требуют следующие слова:

парох - лат. parochus «настоятель церкви» [EWU 1121]

штримфли - венг. strimfli «чулок»<нем. Strumpf «чулок » [EWU 1362]

ройты - венг. rojt «бахрома» [EWU 1275]

пантлики - венг. pántlika «лента»< нем. bántl, pantl, pant «лента » [EWU 1109]

Или в циркуляре от 01. 03. 1804 года: «Знакомнт'

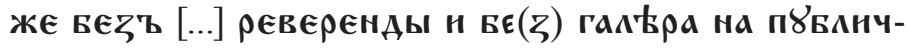

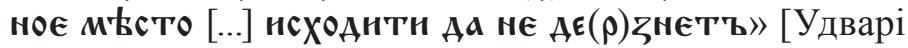
2002:179]. Здесь объяснения требует слово галер - венг. gallér «воротник»< нем. Koller «воротник» [EWU 443].

Среди наиболее часто встречающихся слов можно привести в пример такие слова, как: (фю) ншпднъ «главный выборный чиновник в комитате» - венг. (fö‘ главный’ +) ispán < слав. županz (EWU 626); г8нц४тъ - венг. huncut «смешной, забавный»- нем. Hundsfott «трусливый, смиренный», «самозванец, плут» [EWU 588]; Аоганъ < венг. dohány «табак»-осм.-тур. duhan, duhōn «дым, табак» [EWU 270]; овококъ - венг. ablak «окно» - слав. *obblokъ «кругловатое отверстие» [EWU 2-3] и т. д.

Непременно надо отметить, что иноязычные вкрапления в циркулярах Бачинского встречаются весьма редко. Чаще всего они ощутимы в непосредственных формулировках, в лексике, употребляемой в повседневной жизни и свойственной разговорному стилю. 


\section{Литература}

Падяк 2011 - Падяк В. Неизвістні кириличні уббіжникы Андрія Бачинського. In memoriam István Udvari (19502005). Материалы конференции памяти Иштвана Удвари. Nyíregyháza, 2011. С. 305-326.

Удвари 1986 - Удвари И. Данные о закарпатско-украинской официально-деловой письменности XVIII в. (О гайдудорогских годах Григория Тарковича) // Studia Slavica Hung. 32. Budapest, 1986. C. 63-100.

Удварі 2000 - Удварі І. Образчикы з історії пудкарпатськых Русину в XVIII. столїтіє. Изглядованя з історії культуры и языка. Ужгород, 2000.

Удварі 2002 - Удварі І. Збирькажерел про студії русинського писемства I: Кириличні уббіжникы мукачовського єпископства Андрія Бачинського. Нїредьгаза, 2002.

\section{Источники:}

Мъсяцеслов 1864 - Мђсяцесловъ на годъ высокосный, или переступный 1864. Унгваръ.

Чудиновъ 1894 - А. Н.Чудиновъ. Словарь иностранныхъ словъ, вошедшихъ въ составъ русскаго языка. С. Петербургъ, 1894.

$\boldsymbol{E} \boldsymbol{W} \boldsymbol{U}$ - Etymologisches Wörterbuch Ungarischen I-II. Főszerk. Benkő Loránd. Budapest, Akadémiai Kiadó, 1993-1995.

\section{Marianna Lyavinecz-Ugrin}

Eötvös Loránd University, Hungary

mariann.ljavinecz@gmail.com

\section{AzBukiVedi (Andrey Bachinsky Vladyka (bishop)) Cyrillic Circulars of Bishop A. Bachinsky}

This article summarizes some information about the manuscripts of Bishop Andrei Bachinsky. We will present some Cyrillic circulaires and the peculiarities of the writing traditions of Carpatho Rusyns.

Key words: Andrey Bachinsky, Cyrillic circulaires of the Latin period, Carpatho Rusyns 